\title{
STUDI DAMPAK COVID-19 TERHADAP HASIL BELAJAR GEOGRAFI DI SMA NEGERI 1 SIKUR
}

\author{
Animar' ${ }^{1}$, Siti Arni Wulandya ${ }^{2 *}$ \\ ${ }^{1}$ SMA Negeri 1 Sikur, Lombok Timur, Indonesia \\ ${ }^{2}$ Program Studi Statistika, Fakultas Matematika dan Ilmu Pengetahuan Alam, Universitas Hamzanwadi, Selong, Indonesia \\ *Email Koresponden: wuland9302@gmail.com
}

Diterima: 26-12-2020, Revisi: 27-12-2020, Disetujui: 28-12-2020

(C)2020 Program Studi Pendidikan Geografi, FISE, Universitas Hamzanwadi

\begin{abstract}
Abstrak Penyebaran virus Corona berdampak signifikan pada dunia pendidikan. Kebijakan yang diambil oleh banyak negara termasuk Indonesia adalah dengan meliburkan seluruh aktivitas pendidikan. Hal ini membuat pemerintah dan lembaga terkait harus menghadirkan alternatif proses pembelajaran. Banyak faktor yang mempengaruhi hasil belajar siswa ditambah dengan perubahan kondisi pembelajaran akibat wabah virus Corona (Covid-19). Tujuan dari penelitian ini adalah untuk mendapatkan informasi mengenai dampak dan kendala dari wabah COVID-19 terhadap kegiatan belajar mengajar khususnya pada mata pelajaran Geografi di SMA Negeri 1 Sikur. Pengumpulan data dilakukan dengan dengan metode pretest - posttest kemampuan siswa sebelum dan setelah adanya pandemi Covid-19. Selanjutnya analisis data dilakukan dengan metode kuantitatif menggunakan uji t sampel berpasangan (paired sample t-test) untuk menguji perbedaan pengaruh dua perlakuan pada kelompok sampel yang saling berhubungan. Hasil analisis mengindikasikan bahwa terdapat perbedaan rata-rata hasil belajar Geografi siswa kelas XI IPS saat sebelum dengan setelah terjadinya wabah virus corona. Diperoleh informasi bahwa nilai rata-rata hasil belajar siswa pada saat proses pembelajaran dilakukan secara tatap muka sebesar 86,27 lebih baik dibandingkan nilai rata-rata saat proses pembelajaran dilakukan secara online yaitu sebesar 75,73 .
\end{abstract}

Kata kunci: dampak covid-19, hasil belajar, geografi

\begin{abstract}
The spread of the Corona virus has had a significant impact on the world of education. The policy taken by many countries, including Indonesia, is to close all educational activities. This makes the government and related institutions have to present an alternative learning process. Many factors affect student learning outcomes coupled with changes in learning conditions due to the Corona virus (Covid-19) outbreak. The purpose of this study was to obtain information about the impacts and constraints of the Covid-19 outbreak on teaching and learning activities, especially in Geography subjects at SMA Negeri 1 Sikur. Data collection was carried out using the pretest - posttest method of students' abilities before and after the Covid-19 pandemic. Furthermore, data analysis was carried out by quantitative methods using paired sample t-test to test the difference in the effect of the two treatments on the interrelated sample groups. The results of the analysis indicate that there is a difference in the average Geography learning outcomes of $11^{\text {th }}$ grade of social science students before and after the outbreak of the corona virus. Information was obtained that the average value of student learning outcomes during the face-to-face learning process was 86.27, better than the average value when the learning process was carried out online which was 75.73 .
\end{abstract}

Keywords: covid-19 impact, learning outcomes, geography

\section{PENDAHULUAN}

Awal tahun 2020 ini dunia digemparkan dengan mewabahnya sebuah virus mematikan yang dikenal dengan Corona atau Covid-19. Virus ini mulai mewabah akhir tahun 2019 di kota Wuhan, China kemudian mewabah dengan cepat ke seluruh dunia. Hingga pada Maret 2020 WHO menetapkan wabah virus ini sebagai pandemi global. Jutaan manusia telah menjadi korban dari virus mematikan ini (Kompas.com, 2020). Hingga akhir 2020, kasus positif Covid-19 yang terdeteksi mencapai 75,5 juta kasus dengan jumlah kematian mencapai 1,7 juta jiwa di seluruh dunia (The New York Times, 2020). Banyaknya korban berjatuhan disebabkan karena penularannya yang sangat cepat dan sulitnya 
mendeteksi orang yang terpapar karena masa inkubasi dari virus ini yang cukup lama yaitu dua minggu. Selain itu penyebab terbesarnya adalah penularan melalui kontak antar individu dalam interaksi sosial yang sulit dihindari sementara vaksin untuk virus ini belum ditemukan dan korban terpapar terus berjatuhan diiringi dengan terbatasnya fasilitas dan tenaga kesehatan.

Penanganan wabah Covid-19 yang cukup rumit mengakibatkan hampir seluruh pemimpin negara di dunia membuat kebijakan yang cukup ketat untuk memutus mata rantai penyebaran virus Covid-19. Social distancing atau Pembatasan Sosial Berskala Besar (PSBB) menjadi pilihan berat yang harus diterapkan di beberapa Negara (Buana, 2020). Social distancing atau Pembatasan Sosial Berskala Besar (PSBB) ini mengakibatkan terhambatnya aktivitas dalam banyak bidang kehidupan salah satunya aktivitas belajar mengajar di sekolah. Kebijakan social distancing ini menyebabkan di tutup sementaranya sekolah-sekolah dan lembaga pendidikan lainnya. Jutaan pelajar di dunia terdampak akibat ditutup sementaranya lembaga pendidikan sebagai upaya menekan penyebaran virus covid-19 tidak terkecuali pada siswa SMA Negeri 1 Sikur. Kebijakan ini menyebabkan gangguan dalam proses belajar mengajar di sekolah dan secara tidak langsung berdampak pada psikologis anak didik dan menurunnya minat belajar serta kualitas keterampilan siswa. Kondisi ini menjadi tanggung jawab semua pihak agar menjamin keberlangsungan pembelajaran jarak jauh (Firman \& Rahayu, 2020).

Kegiatan belajar mengajar di sekolah merupakan salah satu kebijakan publik terbaik sebagai upaya untuk meningkatkan pengetahuan dan kemampuan siswa. Sebagian besar orang beranggapan bahwa sekolah adalah kegiatan yang sangat menyenangkan dan salah satu tempat interaksi sosial cukup besar terjadi. Sekolah dapat meningkatkan keterampilan dan kesadaran sosial siswa. Tetapi sekarang kegiatan belajar mengajar di sekolah harus terhenti tiba-tiba karena mewabahnya virus Covid-19. Dampak dihentikannya proses belajar mengajar di sekolah tidak hanya mempengaruhi produktivitas siswa dan guru saja namun juga dapat berakibat pada pertumbuhan ekonomi. Keadaan ini bukanlah kondisi yang ideal. Kehilangan waktu belajar di sekolah secara signifikan mengakibatkan berkurangnya waktu belajar siswa yang mengakibatkan menurunnya kesempatan siswa untuk memperoleh pengetahuan secara langsung dari guru. Kondisi ini harus segera diatasi. Jika dalam keadaan normal saja, di Indonesia masih terjadi ketimpangan antar daerah apalagi hambatannya ditambah dengan kondisi pandemi saat ini.

Saat ini, Kementerian Pendidikan di bawah pimpinan Menteri Nadiem Makarim, mendengungkan semangat untuk meningkatkan produktivitas siswa untuk membuka peluang kerja ketika telah menjadi lulusan nanti. Namun adanya wabah Covid-19 yang sangat mendadak, maka dunia pendidikan Indonesia perlu membuat suatu sistem pembelajaran yang dapat membantu sekolah dalam kondisi darurat. Dalam masa darurat pandemi ini, sekolah diharuskan tetap melaksanakan proses pembelajaran melalui media dari daring (online). Namun penggunaan teknologi jarak jauh dalam sistem pembelajaran ini menemukan beberapa kendala terutama pada guru dan siswa yang melaksanakan proses pembelajaran.

Penyebaran virus corona ini pada awalnya sangat berdampak pada dunia ekonomi yang mulai lesu, tetapi kini dampaknya dirasakan juga oleh dunia pendidikan. Kebijakan yang diambil oleh banyak negara termasuk Indonesia dengan meliburkan seluruh aktivitas pendidikan, membuat pemerintah dan lembaga terkait harus menghadirkan alternatif proses pendidikan bagi peserta didik maupun mahasiswa yang tidak bisa melaksanakan proses pembelajaran langsung pada lembaga pendidikan. Berdasarkan data yang diperoleh dari UNESCO (Kompas.com, 2020), hingga Maret 2020 terdapat 39 negara yang menerapkan penutupan sekolah dengan total jumlah pelajar yang terpengaruh mencapai 421.388 .462 anak. China sejauh ini memiliki jumlah pelajar yang paling banyak terpengaruh karena virus Corona yaitu sekitar lebih dari 233 juta siswa. Sedangkan negara lainnya, hingga 13 Maret ada 61 negara di Afrika, Asia, Eropa, Timur Tengah, Amerika Utara dan Amerika Selatan yang telah mengumumkan atau menerapkan pembatasan pembelajaran sekolah dan universitas.

UNESCO menyediakan dukungan langsung ke negara-negara yang terdampak Covid-19, termasuk solusi untuk pembelajaran jarak jauh yang inklusif. Kebijakan menutup sekolah di negaranegara tersebut, berdampak pada hampir 421,4 juta anak-anak dan remaja di dunia. Negara yang terkena dampak Covid-19 menempatkan respons nasional dalam bentuk platform pembelajaran dan perangkat lain seperti pembelajaran jarak jauh. Dalam situs UNESCO dikemukakan bahwa pandemi corona ini mengancam 577 juta pelajar di dunia. Sementara UNESCO menyebutkan, total ada 39 negara yang 
menerapkan penutupan sekolah dengan total jumlah pelajar yang terpengaruh mencapai 421.388 .462 anak.

Total jumlah pelajar yang berpotensi berisiko dari pendidikan pra-sekolah dasar hingga menengah atas adalah 577.305.660. Sedangkan jumlah pelajar yang berpotensi berisiko dari pendidikan tinggi sebanyak 86.034.287 orang. Saat ini di Indonesia, sebagian besar kampus dan sekolah mulai menerapkan kebijakan kegiatan belajar mengajar dari jarak jauh atau kuliah online. Semua orang lantas mengambil jarak demi memutus rantai penularan Covid-19. Tempat-tempat ibadah kini mulai sepi, agenda-agenda massa dihilangkan, karena virus ini pula istilah Work From Home (WFH) jadi mencuat. Belum cukup sampai sana, sekolah dan kampus pun ikut terimbas didaringkan. Lengkap sudah, virus corona juga memberikan dampak serius di sektor pendidikan, baik di Indonesia maupun secara global. Pemerintah mengumumkan Ujian Nasional (UN) di tahun ini resmi ditiadakan. Mulai dari tingkat Sekolah Dasar (SD) hingga setingkat Sekolah Menengah Atas (SMA). Pemerintah telah meniadakan Ujian Nasional (UN) untuk tahun 2020. Tenaga dan peserta didik di seluruh dunia merasakan betul dampak yang luar biasa dari wabah virus Corona ini. Akibat pandemi ini, hampir semua sekolah terpaksa diliburkan. Sekolah-sekolah itu menampung ratusan juta siswa dari seluruh dunia. Seluruh jenjang pendidikan dari sekolah dasar/ibtidaiyah sampai perguruan tinggi (universitas) baik yang berada di bawah Kementerian Pendidikan dan Kebudayaan RI maupun yang berada di bawah Kementerian Agama RI semuanya memperoleh dampak negatif karena pelajar, siswa dan mahasiswa diharuskan belajar dari rumah karena pembelajaran tatap muka ditiadakan untuk mencegah penularan covid-19. Padahal tidak semua pelajar, siswa dan mahasiswa terbiasa belajar melalui Online. Apalagi guru dan dosen masih banyak belum mahir mengajar dengan menggunakan teknologi internet atau media sosial terutama di berbagai daerah (Abadi \& Muthohirin, 2020).

Geografi merupakan salah satu bidang ilmu yang termasuk dalam Ilmu Pengetahuan Sosial. Ilmu ini mempelajari tentang fenomena-fenomena alam dan manusia yang terjadi di permukaan bumi. Pentingnya mempelajari ilmu geografi mengharuskan setiap orang mampu memahami lingkungan sekitar, fenomena alam dan aktivitas manusia. Karena bagaimanapun manusia tidak dapat dipisahkan dari lingkungan alam dan sekelilingnya. Geografi bukan ilmu yang mengembangkan prinsip, konsep dan teori saja, tetapi juga mampu mengkaji dan menganalisis peristiwa yang terjadi di muka bumi. Pemahaman dan rasa ingin tahu mengenai ilmu geografi di kalangan siswa masih relatif rendah, siswa yang merasa mengantuk dan bosan saat mengikuti pembelajaran Geografi. Tak sedikit juga siswa beranggapan bahwa mempelajari geografi hanya cukup dengan menghafal. Siswa yang mengalami kesulitan belajar, biasanya akan merasa semakin terbebani. Banyak faktor yang mempengaruhi hasil belajar siswa salah satunya adalah kurangnya motivasi belajar geografi, ditambah dengan perubahan kondisi pembelajaran akibat wabah virus corona (Covid-19).

Aji (2020), Purwanto et al., (2020) serta Mastura dan Santaria (2020) telah melakukan penelitian eksploratif untuk melihat dampak Covid-19 terhadap proses pengajaran khususnya bagi tenaga pendidik, peserta didik juga orang tua. Menurut hasil penelitian tersebut terdapat beberapa kendala yang dialami oleh murid, guru dan orang tua dalam kegiatan belajar mengajar online yaitu penguasaan teknologi masih kurang, penambahan biaya kuota internet, adanya pekerjaan tambahan bagi orang tua dalam mendampingi anak belajar, komunikasi dan sosialisasi antar siswa, guru dan orang tua menjadi berkurang dan jam kerja yang menjadi tidak terbatas bagi guru karena harus berkomunikasi dan berkoordinasi dengan orang tua, guru lain, dan kepala sekolah. Dari beberapa penelitian tersebut peneliti bermaksud menggali informasi sejenis namun ditempat dan karakteristik setting penelitian yang berbeda. Adapun tujuan dari penelitian ini adalah untuk mendapatkan informasi secara kuantitatif mengenai dampak pandemi Covid-19 terhadap hasil belajar pada mata pelajaran Geografi di SMA Negeri 1 Sikur menggunakan metode uji t sampel berpasangan (paired sample t-test).

\section{METODE PENELITIAN}

Data yang digunakan dalam penelitian ini adalah data primer yang diperoleh dari hasil observasi pada populasi siswa kelas XI Ilmu Pengetahuan Sosial SMA Negeri 1 Sikur, selanjutnya digunakan 30 sampel dari populasi tersebut. Sampel diobservasi pada dua kondisi yaitu saat sebelum terjadinya pandemi (Februari 2020) dan setelah terjadinya pandemi (Juni, 2020). Variabel yang diamati adalah nilai 
hasil belajar pada mata pelajaran Geografi. Variabel ini akan dibandingkan pada kondisi sebelum proses belajar dengan daring dan setelah proses belajar dengan daring.

Penelitian yang dilakukan adalah penelitian eksperimen yang bertujuan untuk menyelidiki hubungan sebab akibat perlakuan tertentu terhadap suatu variabel kemudian mengobservasi efeknya . Desain eksperimen yang digunakan adalah Pretest-Postest Control Group Design. Langkah-langkah proses pengumpulan data pada percobaan ini sebagai berikut: 1) Data pretest dikumpulkan sebelum terjadinya wabah virus Corona (Covid-19) dimana proses pembelajaran dilakukan secara langsung dengan tatap muka dan menggunakan sarana prasarana di sekolah; 2) Data post test dikumpulkan setelah terjadinya wabah virus Corona (Covid-19) dimana proses pembelajaran tidak dapat dilakukan secara langsung di sekolah, melainkan dengan memanfaatkan bantuan teknologi informasi melalui jejaring internet dan sosial media. Perbelejaran daring (online) di SMA Negeri 1 Sikur memanfaatkan sosial media seperti Whats App, youtube, google form dan google classroom; 3) Selanjutnya data pretest dan postest akan dianalisis menggunakan uji t sampel berpasangan dengan bantuan software SPSS.

Data yang diperoleh pada penelitian ini dianalisis menggunakan metode uji t sampel berpasangan (paired sampel t-test). Uji t sampel berpasangan digunakan apabila dua kelompok sampel saling berhubungan. Ciri-ciri yang paling sering ditemui pada kasus data yang berpasangan adalah satu individu (objek penelitian) mendapat dua buah perlakuan yang berbeda. Meski menggunakan individu yang sama, peneliti tetap memperoleh dua macam data sampel, yaitu data dari perlakuan pertama dan data dari perlakuan kedua. Hipotesis dari kasus ini dapat ditulis:

$$
\begin{aligned}
& H_{0}=\mu_{1}=\mu_{2} \\
& H_{1}=\mu_{1} \neq \mu_{2}
\end{aligned}
$$

Makna dari hipotesis alternatif $\left(H_{1}\right)$ di atas adalah bahwa ada perbedaan rata-rata hasil pengamatan pada kedua perlakuan. Statistik uji yang digunakan untuk melakukan uji t sampel berpasangan ini adalah:

$$
t_{\text {hitung }}=\frac{\bar{D}}{\frac{S D}{\sqrt{n}}}
$$

Sumber: Montolalu, \& Langi (2018).

Keterangan:

$S D=\sqrt{\text { variansi }}$

variansi $\left(s^{2}\right)=\frac{\sum_{i=1}^{n}\left(x_{i}-\bar{x}\right)^{2}}{n-1}$

$t \quad=$ nilai $t$ hitung

$\bar{D}=$ rata - rata selisih perlakuan 1 dan 2

$S D=$ standar deviasi selisih perlakuan 1 dan 2

$n=$ jumlah sampel

Interpretasi dari hasil uji t sampel berpasangan dapat diambil jika terlebih dahulu ditentukan: 1) Nilai signifikansi $\alpha$; 2) Df (degree of freedom) $=\mathrm{N}-1$; 3) Bandingkan nilai $t_{\text {hit }}$ dengan $t_{t a b=\alpha ; n-1}$. Apabila $t_{\text {hit }}>t_{\text {tab }}$ maka $H_{0}$ ditolak artinya ada perbedaan signifikan antara rata-rata kedua perlakuan sedangkan jika $t_{h i t}<t_{t a b}$ maka $H_{0}$ diterima artinya tidak ada perbedaan signifikan antara rata-rata kedua perlakuan.

\section{TEMUAN DAN PEMBAHASAN}

Data pretest dalam penelitian ini ditentukan melalui nilai hasil belajar siswa sebelum virus Corona (Covid-19) mewabah, sedangkan data postest dalam penelitian ini ditentukan melalui nilai hasil belajar siswa setelah virus Corona (Covid-19) mewabah. Hal ini bertujuan untuk dapat melihat dan memberikan penilaian atas perbandingan ke dua data tersebut. Dengan demikiann akan diperoleh data perbandingan yang jelas. Dengan adanya perbandingan data tersebut maka akan mempermudah dalam analisis selanjutnya. Adapun data kedua perlakuan dapat dilihat pada Tabel 1. 
Tabel 1. Nilai observasi hasil belajar Geografi 30 siswa

\begin{tabular}{cccccc}
\hline No & Pretest & Postest & No & Pretest & Postest \\
\hline 1 & 86 & 75 & 16 & 98 & 80 \\
2 & 95 & 80 & 17 & 87 & 75 \\
3 & 79 & 78 & 18 & 82 & 74 \\
4 & 100 & 80 & 19 & 80 & 70 \\
5 & 84 & 85 & 20 & 79 & 72 \\
6 & 90 & 80 & 21 & 75 & 69 \\
7 & 85 & 75 & 22 & 98 & 80 \\
8 & 78 & 75 & 23 & 86 & 78 \\
9 & 98 & 80 & 24 & 87 & 70 \\
10 & 94 & 80 & 25 & 89 & 74 \\
11 & 98 & 80 & 26 & 90 & 82 \\
12 & 85 & 75 & 27 & 76 & 65 \\
13 & 74 & 65 & 28 & 89 & 79 \\
14 & 83 & 76 & 29 & 79 & 65 \\
15 & 80 & 75 & 30 & 84 & 80 \\
\hline
\end{tabular}

Sumber: Hasil olahan data primer, 2020.

Hasil analisis data pada Tabel 1 menggunakan software SPSS 20 diberikan pada Tabel 2 dan Tabel 3 di bawah ini.

Tabel 2. Paired Samples Test

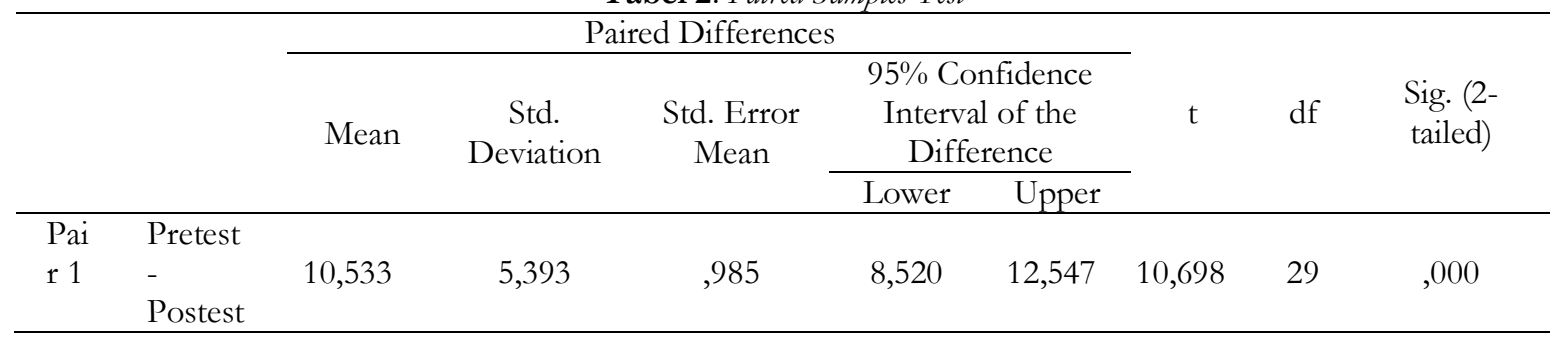

Sumber: Hasil analsis penelitian, 2020.

Tabel 2 menunjukkan hasil uji t sampel berpasangan dimana diperoleh $\mathrm{t}$ hitung sebesar 10,698 dengan nilai Sig. sebesar 0,000 . Hipotesis awal $\left(\mathrm{H}_{0}\right)$ di tolak jika nilai $\mathrm{t}_{\text {hitung }}>\mathrm{t}_{(0,05 ; 29)}$ sehingga dengan menggunakan tingkat signifikansi $\propto=0,05$ diperoleh nilai $\mathrm{t}_{(0,05 ; 2)}=2,045$ artinya hipotesis awal tersebut ditolak. Penolakan $\mathrm{H}_{0}$ mengindikasikan bahwa terdapat perbedaan rata-rata hasil belajar Geografi siswa kelas XI IPS saat sebelum terjadinya wabah virus corona dengan setelah terjadinya wabah virus Corona. Adanya perbedaan ini menunjukkan bahwa nilai hasil belajar siswa pada saat proses belajar mengajar dilakukan secara online mengalami perubahan secara signifikan dibandingkan saat proses pembelajaran dilakukan secara langsung dengan tatap muka. Perbedaan nilai hasil belajar dari kedua perlakuan ditunjukkan oleh Tabel 3 di bawah ini.

Tabel 3. Paired Samples Statistics

\begin{tabular}{cccccc}
\hline & Mean & N & $\begin{array}{c}\text { Std. } \\
\text { Deviation }\end{array}$ & $\begin{array}{c}\text { Std. Error } \\
\text { Mean }\end{array}$ \\
\hline \multirow{2}{*}{ Pair 1 } & Sebelum & 86,27 & 30 & 7,543 & 1,377 \\
& Sesudah & 75,73 & 30 & 5,219 &, 953 \\
\hline \multicolumn{2}{l}{ Sumber: Hasil analsis penelitian, 2020 } & &
\end{tabular}

Sumber: Hasil analsis penelitian, 2020. 
Berdasarkan hasil analisis data yang ditampilkan pada tabel 3, diketahui bahwa nilai rata-rata hasil belajar siswa pada saat proses pembelajaran dilakukan secara tatap muka sebesar 86,27 lebih baik dibandingkan nilai rata-rata saat proses pembelajaran dilakukan secara online yaitu sebesar 75,73. Turunnya nilai hasil belajar pada saat proses pembelajaran dilakukan secara online disebabkan karena terjadinya adaptasi pada proses belajar mengajar baik pada siswa yang menerima pelajaran juga pada sisi guru yang menyiapkan pembelajaran. Siswa, guru dan pihak sekolah banyak yang mengalami culture shock, yaitu istilah yang digunakan untuk menggambarkan perasaan terkejut atau bingung yang dirasakan seseorang apabila bersentuhan dengan budaya atau keadaan yang berlainan satu sama lain. Culture shock yang dialami siswa, guru dan pihak sekolah selama proses pembelajaran dalam hal teknologi informasi. Sebelum wabah Corona terjadi, proses belajar mengajar di sekolah sebagian besar masih menggunakan metode konvensional. Terlepas dari penggunaan komputer sebagai media belajar, pembelajaran secara online masih sangat terbatas digunakan. Sehingga saat virus mematikan seperti Corona ini mewabah dan membatasi ruang gerak manusia termasuk dalam hal pendidikan, banyak pihak yang mengalami kendala untuk menyesuaikan diri. Tidak sedikit siswa yang terkendala mengikuti pembelajaran online karena keterbatasan secara ekonomi, seperti tidak punya komputer, laptop atau handphone yang memadai untuk pelaksanaan pembelajaran online juga keterbatasan dana untuk membeli paket internet selama belajar online dilakukan. Sementara itu tidak sedikit guru-guru masih perlu belajar bagaimana memanfaat teknologi informasi agar bisa digunakan secara efektif selama proses pembelajaran. Kendala-kendala ini menjadi salah satu penyebab utama turunnya nilai hasil belajar siswa selama masa pandemi ini.

Berkaitan dengan pengaruh Covid-19 terhadap bidang pendidikan, Aji (2020) menyampaikan tentang keprihatinannya terhadap situasi dunia pendidikan sebagai akibat dari pandemi virus Corona. Ia menyampaikan bahwa proses pembelajaran di sekolah merupakan alat kebijakan publik terbaik sebagai upaya peningkatan pengetahuan dan keterampilan peserta didik. Selain itu banyak siswa menganggap bahwa sekolah adalah kegiatan yang sangat menyenangkan. Para siswa bisa berinteraksi satu sama lain. Sekolah dapat meningkatkan keterampilan sosial dan kesadaran sosial siswa. Sekolah secara keseluruhan adalah media interaksi antar siswa dan guru untuk meningkatkan kemampuan intelegensi, ketrampilan dan rasa kasih sayang di antara mereka. Tetapi kegiatan yang bernama proses pembelajaran di sekolah berhenti dengan tiba-tiba karena mengantisipasi gangguan ancaman dari pandemi Covid-19 bagi dunia pendidikan khususnya bagi peserta proses belajar tersebut. Kegiatan belajar dialihkan menjadi metode pembelajaran jarak jauh dengan menggunakan sistem daring. Pengalihan ini tentu memiliki dampak yaitu dari proses belajar di sekolah kemudian dialihakan menjadi pembelajaran dari rumah.

Pada sebuah artikel dijelaskan bahwa para remaja di Swedia memiliki jumlah hari yang berbeda untuk mempersiapkan diri menghadapi test penting. Perbedaan-perbedaan ini bersifat acak kondisional yang penulis coba mengasumsikan kondisi yang sama di Indonesia. Para remaja di Swedia itu menambah belajar selama sepuluh hari sekolah dan hasil yang mereka dapatkan adalah meningkatkan skor pada tes pengetahuan mereka. Begitu juga ketika merujuk Jonsson, bahwa menghadiri sekolah akan meningkatkan kapasitas memori murid. Merujuk Carlsson jika pada tes penggunaan pengetahuan dan diasumsikan setiap kehilangan masa bersekolah selama 10 hari adalah 1 persen dari standar deviasi maka siswa sekolah dalam 12 minggu atau 60 hari sekolah mereka akan kehilangan $6 \%$ dari setandar deviasi. Kondisi ini bukan masalah sepele. Siswa akan mengalami gangguan dalam pengetahuan untuk masa datang dan juga dengan masalah pengetahuan yang lebih kompleks.

Selain kesulitan belajar, gangguan kesehatan mental juga akan banyak mempengaruhi keadaan psikis peserta didik dimana situasi saat ini menuntut peserta didik untuk waspada dengan lingkungan dimana mereka hidup sehari-hari. Kondisi ini menimbulkan gangguan kesehatan mental salah satunya yaitu gangguan psikomatik, rasa cemas, panik dan ketakutan adalah sebab utama gangguan ini berkelakar dalam tubuh manusia. Sugesti yang dibangun dalam pikiran sangat berpengaruh terhadap kondisi fisik dan psikis di situasi ini. Psikomatik akan timbul (Nurkholis, 2020). Kesamaan situasi Indonesia dengan negara-negara lain di belahan dunia mesti segera diatasi dengan seksama. Dalam keadaan normal saja banyak ketimpangan yang terjadi antardaerah. Kementerian Pendidikan di bawah kepemimpinan Menteri Nadiem Makarim, mendengungkan semangat peningkatan produktivitas bagi siswa untuk mengangkat peluang kerja ketika sudah lulu dari sekolah. Namun dengan hadirnya pandemi Covid-19 yang sangat mendadak, maka dunia pendidikan Indonesia perlu mengikuti alur yang sekiranya 
dapat menolong kondisi sekolah dalam keadaan darurat. Sekolah perlu memaksakan diri menggunakan media daring. Namun penggunaan teknologi bukan tidak ada masalah, banyak kendala atau masalah yang menghambat terlaksananya efektivitas pembelajaran dengan metode daring (Pujilestari, 2020).

Kendala pertama yang dapat disebutkan adalah keterbatasan penguasaan teknologi informasi oleh guru dan siswa. Kondisi guru di Indonesia tidak seluruhnya paham penggunaan teknologi, ini bisa dilihat dari guru-guru yang lahir tahun sebelum 1980-an. Kendala teknologi informasi membatasi mereka dalam menggunakan media daring. Begitu juga dengan siswa yang kondisinya hampir sama dengan guru-guru yang dimaksud dengan pemahaman penggunaan teknologi. Kendala kedua menyangkut sarana dan prasarana yang masih kurang memadai karena minimnya persiapan. Ancaman covid-19 yang datang tiba-tiba mengubah cara belajar yang selama ini menggunakan tatap muka lalu menggunakan cara daring. Cara ini membutuhkan perangkat tambahan yang harus dimiliki tidak hanya oleh pendidik melainkan juga oleh peserta didik. Sementara itu perangkat pendukung yang berbasis pada teknologi tersebut tentu bukan harga yang murah. Masih banyak daerah di Indonesia yang guru pun masih dalam kondisi ekonomi yang mengkhawatirkan. Kesejahteraan guru maupun murid membatasi mereka yang masih sangat serba terbatas hidupnya mengalami kesulitan dalam menyediakan sarana dan prasarana teknologi informasi yang sangat diperlukan dengan model pembelajaran selama musibah pandemi Covid-19 ini berlangsung.

Ketiga berkaitan dengan akses Internet yang masih terbilang bersifat terbatas. Jaringan internet yang benar-benar kuat dan memadai masih belum merata di pelosok negeri di Indonesia. Tidak semua lembaga pendidikan baik Sekolah Dasar maupun Sekolah Menengah dapat menjangkau fasilitas internet yang memadai sebagai sarana belajar. Jika ada jaringan internet kondisinya masih belum mampu berfungsi dengan baik di dalam pembelajaran dengan menggunakan media daring (Purwanto et al., 2020). Selain itu, masalah lain yang mengikutinya adalah mengenai ketersediaan anggaran yang terbatas. Dari segi biaya juga menjadi sesuatu yang menghambat karena aspek kesejahteraan guru dan murid masih banyak yang tergolong jauh dari harapan. Ketika mereka menggunakan kuota internet untuk memenuhi kebutuhan media daring, maka jelas mereka tidak sanggup membayarnya.

Ada dilema dalam pemanfaatan media daring, ketika menteri pendidikan memberikan semangat produktivitas harus melaju, namun di sisi lain kecakapan dan kemampuan finansial guru dan siswa belum melaju dengan arah yang sama. Negara pun belum hadir secara menyeluruh dalam memfasilitasi kebutuhan biaya yang dimaksud. Akibat dari kendala-kendala seperti yang disebutkan di atas kemudian timbul beberapa dampak yang kurang menguntungkan khususnya dari peserta didik. Akibat dari proses pembelajaran jarak jauh yang terjadi secara mendadak dan tidak terencana menyebabkan terjadinya hambatan dalam transfer pengetahuan. Sebagai akibat dari penutupan gedung-gedung sekolah terjadi kesulitan pada anak-anak dalam menguasai pengetahuan dan kemampuan sesuai tingkatan kelas yang diharapkan. Dengan berkurangnya waktu belajar dan juga tidak terjadinya tatap muka secara langsung, tentu hal ini akan berisiko terhadap penyerapan materi yang seharusnya dapat dikuasai. Ini juga berdampak pada peningkatan anak yang putus sekolah akibat kesulitan yang dihadapi anak dan remaja untuk kembali dan tetap bersekolah setelah penutupan sekolah dan kontraksi ekonomi yang berlangsung dalam waktu lama.

Pandemi Covid-19 saat ini telah menghantarkan dunia pada era kekhawatiran namun juga sekaligus memberi tantangan yang harus dihadapi. Di tengah kekhawatiran dan kecemasan, ada tantangan yang harus dilewati. Tantangan ini sesungguhnya dapat menciptakan peluang baru baik dalam mengatasi persoalan yang sedang dihadapi maupun sebagai antisipasi perkembangan dunia selanjutnya. Secara umum pandemi covid-19 ini banyak menimbulkan ancaman bagi dunia pendidikan. Namun, jika kita dapat melihat dari sudut pandang berbeda, ancaman ini justru dapat menjadi peluang dan batu loncatan untuk memajukan dunia pendidikan (Pujilestari, 2020). Pandemi Covid-19 yang dinilai membawa begitu banyak dampak negatif, ternyata juga membawa dampak positif bagi dunia pendidikan. Dampak positif ini dapat menjadi motivasi untuk melewati masa-masa sulit di tengah pandemi dan tetap fokus meraih tujuan pendidikan Indonesia yang lebih maju.

Beberapa dampak positif yang dapat terjadi di tengah pandemi Covid-19 adalah yang pertama dapat disebutkan yaitu bahwa keadaan ini dapat menjadi pemicu percepatan transformasi pendidikan. Pandemi Covid-19 telah menyebabkan penutupan gedung-gedung sekolah dalam upaya menghentikan 
penyebaran virus tersebut. Sebagai gantinya, pemerintah telah memberlakukan sistem Pendidikan Jarak Jauh (PJJ). Sistem PJJ yang berbasis teknologi tentu mengharuskan lembaga pendidikan, guru, siswa bahkan orang tua agar terampil di dalam mengoperasikan teknologi komputer dengan baik. Proses pembelajaan ini dapat menjadi pemicu percepatan transformasi teknologi pendidikan di Indonesia. Ini tentu berdampak positif karena penggunaan teknologi dalam pendidikan selaras dengan perkembangan era revolusi Industri 4.0 yang terus berkembang maju (Pakpahan \& Fitriani, 2020).

Kemudian dari situasi pandemi ini banyak muncul aplikasi belajar berbasis online. Percepatan transformasi teknologi pendidikan karena pandemi Corona membuat berbagai platform meluncurkan berbagai aplikasi belajar online guna mendukung PJJ. Banyak muncul aplikasi belajar online membuat belajar \#DariRumahAja tetap dapat dilakukan dengan efektif. Aplikasi-aplikasi belajar online dikembangkan dengan penyediaan fitur-fitur yang memudahkan dalam menjalankan belajar online. Juga muncul kursus online gratis. Kursus online gratis mulai marak di tengah pandemi Covid-19. Banyak lembaga bimbingan belajar memberikan kursus online gratis atau ada yang memberikan dengan potongan harga (Windhiyana, 2020). Di sisi lain karena keadaan yang memaksa untuk berada di dalam keterbatasan justru menjadi pemicu muncul kreativitas tanpa batas. Pandemi Covid-19 ternyata menimbulkan ide-ide baru. Para ilmuwan, peneliti, dosen bahkan mahasiswa berupaya melakukan eksperimen untuk menemukan vaksin Covid-19. Seperti yang dilakukan oleh alumni UGM yang membantu mengatasi kekurangan masker dengan membuat masker yang bisa dicuci ulang. Tidak hanya itu, kreativitas lain yang juga tidak kalah menarik, seperti mahasiswa Rumah Bahasa UI yang menjadi relawan Covid-19 dan membantu mengedukasi masyarakat. Para pengajar menemukan cara daring atau pembelajaran jarak jauh untuk mata pelajaran yang yang berbasis praktek maupun aktivitas fisik (Herlina \& Suherman, 2020).

Selain itu, hal yang lebih luar biasa lagi bahwa pendidikan membangkitkan kembali kolaborasi orang tua dan guru. Selama masa pandemi ini, peserta didik tentu akan menghabiskan waktu belajar di rumah. Di mana ini menuntut adanya kolaborasi yang inovatif antara orang tua dan guru sehingga peserta didik tetap bisa menjalani belajar online dengan efektif. Selain itu, kolaborasi yang inovatif dapat mengatasi berbagai keluhan selama menjalani belajar online. Ini akan memberikan dampak positif bagi dunia pendidikan baik di masa kini maupun masa mendatang (Mansyur, 2020).

\section{SIMPULAN}

Pembatas sosial berskala besar termasuk pada proses pembelajaran di sekolah selama masa pandemi virus Corona mempengaruhi perbedaan nilai hasil belajar siswa pada mata pelajaran Geografi. Banyaknya keterbatasan akibat pembelajaran secara online selama masa pendemi mengakibatkan turunnya rata-rata nilai hasil belajar Geografi siswa secara signifikan. Hasil uji t sampel berpasangan mengindikasikan bahwa terdapat perbedaan rata-rata hasil belajar Geografi siswa kelas XI IPS saat sebelum terjadinya wabah virus Corona dengan setelah terjadinya wabah virus Corona. Diperoleh informasi bahwa nilai rata-rata hasil belajar siswa pada saat proses pembelajaran dilakukan secara tatap muka sebesar 86,27 lebih baik dibandingkan nilai rata-rata saat proses pembelajaran dilakukan secara online yaitu sebesar 75,73. Banyak aspek yang perlu dibenahi dalam proses pembelajaran online dan harus disiapkan sebaik mungkin untuk menunjang tetap terlaksanakannya proses pembelajaran yang efektif meskipun tidak dilaksanakan di sekolah.

\section{DAFTAR PUSTAKA}

Abadi, M., \& Muthohirin, N. (2020). Metode Cultural Responsive Teaching dalam Pendidikan Agama Islam: Studi Kasus Tindak Xenophobia dan Rasisme di Tengah Bencana Covid-19. Progresiva: Jurnal Pemikiran dan Pendidikan Islam, 9(1), 34-48.

Aji, R. H. S. (2020). Dampak Covid-19 pada Pendidikan di Indonesia: Sekolah, Keterampilan, dan Proses Pembelajaran. Salam: Jurnal Sosial dan Budaya Syar-I, 7(5), 395-402.

Buana, D. R. (2020). Analisis Perilaku Masyarakat Indonesia dalam Menghadapi Pandemi Virus Corona (Covid-19) dan Kiat Menjaga Kesejahteraan Jiwa. Salam: Jurnal Sosial dan Budaya Syar-i, 7(3), 217226. 
Firman, F., \& Rahayu, S. (2020). Pembelajaran Online di Tengah Pandemi Covid-19. Indonesian Journal of Educational Science (IJES), 2(2), 81-89.

Herlina, H., \& Suherman, M. (2020). Potensi Pembelajaran Pendidikan Jasmani Olahraga dan Kesehatan (Pjok) Di Tengah Pandemi Corona Virus Disease (Covid)-19 Di Sekolah Dasar. Tadulako Journal Sport Sciences And Physical Education, 8(1), 1-7.

Kompas.com. (2020, 3 Desember). Timeline Wabah Virus Corona, Terdeteksi pada Desember 2019 hingga Jadi Pandemi Global. Diakses pada 18 Desember 2020, dari https://www.kompas.com/tren/read/2020/03/12/113008565/timeline-wabah-virus-coronaterdeteksi-pada-desember-2019-hingga-jadi?page=all.

Mansyur, A. R. (2020). Dampak Covid-19 Terhadap Dinamika Pembelajaran di Indonesia. Education and Learning Journal, 1(2), 113-123.

Mastura, M., \& Santaria, R. (2020). Dampak Pandemi Covid-19 Terhadap Proses Pengajaran Bagi Guru dan Siswa. Jurnal Studi Guru Dan Pembelajaran, 3(2), 289-295.

Montolalu, C., \& Langi, Y. (2018). Pengaruh Pelatihan Dasar Komputer dan Teknologi Informasi bagi Guru-Guru dengan Uji-T Berpasangan (Paired Sample T-Test). d'Cartesian, 7(1), 44-46.

Nurkholis. (2020). Dampak Pandemi Novel-Corona Virus Disease (Covid-19) Terhadap Psikologi dan Pendidikan serta Kebijakan Pemerintah. Jurnal PGSD, 6(1), 39-49.

Pakpahan, R., \& Fitriani, Y. (2020). Analisa Pemanfaatan Teknologi Informasi dalam Pembelajaran Jarak Jauh di Tengah Pandemi Virus Corona Covid-19. Journal of Information System, Applied, Management, Accounting and Research, 4(2), 30-36.

Pujilestari, Y. (2020). Dampak Positif Pembelajaran Online dalam Sistem Pendidikan Indonesia Pasca Pandemi Covid-19. Adalah: Buletin Hukum dan Keadilan, 4(1), 49-56.

Purwanto, A., Pramono, R., Asbari, M., Hyun, C. C., Wijayanti, L. M., \& Putri, R. S. (2020). Studi Eksploratif Dampak Pandemi Covid-19 Terhadap Proses Pembelajaran Online di Sekolah Dasar. EduPsyCouns: Journal of Education, Psychology and Counseling, 2(1), 1-12.

The New York Times. (2020, 15 Desember). JHU CSSE Covid-19 Data. Diakses pada 18 Desember 2020, dari https:// news.google.com/covid19/map?hl=id\&gl=ID\&ceid=ID\%3Aid.

Windhiyana, E. (2020). Dampak Covid-19 Terhadap Kegiatan Pembelajaran Online di Sebuah Perguruan Tinggi Kristen di Indonesia. Perspektif Ilmu Pendidikan, 34(1), 1-8. 